\title{
Student First-Time Voters' Perception in Jakarta Toward Election System in Indonesia: Through Their Participation in Election
}

\section{Martini ${ }^{1}$, Irawaty ${ }^{2}$, and Efridani Lubis ${ }^{3}$}

${ }^{1}$ Education of Social Science, Faculty of Social Sciences, Universitas Negeri Jakarta, Indonesia ${ }^{2}$ Pancasila and Civic Education, Faculty of Social Sciences, Universitas Negeri Jakarta, Indonesia

${ }^{3}$ Faculty of Law, Universitas Islam AsSyafiiyah, Indonesia

\section{Abstract}

General elections are a common mechanism in the democratic political systems adopted by 237 geographies around the globe. Indonesia has been committed to implement the democracy since the first general election in 1955. In the system, first time voters hold a very important role (this demographic accounted for 5 million voters in the 2019 election). The majority of first-time voters are first-year college students. This educated group is not only often viewed as a role model for the larger peer group regarding participation in the political system, but also represents the nation's future leaders, so that their participation in politics is vital to the future continuation of the political systems. This is the main reason for doing research in measuring perception and participation of first-time voters. Similar studies have already taken place, especially in Jakarta, but the main difference in this study relates to measuring the perception and participation using mix method with qualitative analysis in the end.

Keywords: first time voters, higher education students, perception and participation, election

\section{Introduction}

Election system in Indonesia based on democratic principle which is emphasized on four elements: direct (langsung), general (umum), free (bebas), and secretive (rahasia), which well known as LUBER as its abbreviation. Its implementation from the time of Indonesia independence in 1945 assumed fluctuated relate closely to political system from each administration since then. According to Daniel S. Lev [1], there is a correlation between law and politic; unfortunately, it is always law became an political instrument that always depends political balances, power definition, political ideology evolution, social and economy, and many more.

The notion of relationship between law and politic also impacted to general election S OPEN ACCESS 
formulated in specific regulation to make the impact stronger. The Law No. 7 Year 2017 for example, is formulated in order to make of democratic concept stronger and compatible with changing social and political development. The concept includes protection for first time voters, there is a group of people that fully at age of 17 at 17 April 2019. The protection covers guarantee for this group to use their right to choose in the election upcoming.

Quantitatively, the number of first time voters considered big and their contribution for the victory of presidential candidates also significant. The same phenomenon also applied to election of parliamentary members either for legislative chamber or local representatives, either national or local. In the year 2019, there are 5 million first time voters [2]. From this number there are some challenging and problems that lead to possibility of losing their right to choose in practice. To give a picture of the participation of the group we can see in Table 1.

TABLE 1: Number of First Time Voters Proportion in Selected Areas until 1 September 2019

\begin{tabular}{|c|l|c|c|c|}
\hline No & Election Region & $\begin{array}{r}\text { First Time Voters } \\
\text { Number }\end{array}$ & Registered Voters & Percetage \\
\hline 1 & West Java & 212.749 & 32.636 .846 & $0,65 \%$ \\
\hline 2 & East Java & 174.558 & 30.554 .761 & $0,003 \%$ \\
\hline 3 & Central Java & 154.188 & 27.430 .269 & $0,56 \%$ \\
\hline 4 & North Sumatera & 81.034 & 9.426 .220 & $0,85 \%$ \\
\hline 5 & South Sulawesi & 50.497 & 5.972 .161 & $0,84 \%$ \\
\hline 6 & Banten & 46.260 & 7.452 .971 & $0,62 \%$ \\
\hline 7 & Lampung & 45.873 & 5.914 .926 & $0,77 \%$ \\
\hline 8 & South Sumatera & 40.697 & 5.821 .160 & $0,69 \%$ \\
\hline 9 & East Nusa Tenggara & 35.257 & 3.289 .174 & $1,07 \%$ \\
\hline 10 & Jakarta & 33.855 & 7.211 .891 & $0,47 \%$ \\
\hline
\end{tabular}

From Table 1 above, we can see that first-time voters rather distributed equally with the highest in region East Nusa Tenggara (1,07\%) and the lowest is East Java with $0,003 \%$. However, the overall number of first time voters should be well anticipated and promoted since it contributed significantly to voting numbers.

The participation of first time voters is not only for merry the party, but the most important is the participation describes the perception of the group regarding election system. The perception becomes key elements for the interest and intention of the group for participating in the election system.

Some researches in this area has been conducted which describes the interest of the researchers to elaborate this issue. However most of the subject are high school students and rate of their participation, not touching their perception. While higher 
education student whose first time voters can be identified as a group with more knowledge and understand of election system. Under this assumption, if this group choose to participate in the election system because they know what they have been doing and have certain goal of their conduct.

While the topic of this article is relevant, the definition of the first time voters should be agreed upon. As stated in Article 1 point 34 of the Law No. 7 Year 2017 of General Election, the definition of first time voters could be: "Voters should be an Indonesian Citizen whose age reached full 17 (seventeenth) years old or more, married, or had been married".

According to the Article above, first time voters must be young people age between 17 to 22 years old that engage in election system for the first time. The limitation of age 17 could be less if the person has already married, which is not applicable of young man because the Law No. 1 Year 1974 of Marriage makes a limitation of minimum age for man to marry at age 19 years old.

Since it is the first time for this group to make a choice in election, it is understood if they have a feeling little anxiety or worse do not know what to choose. According to the Ministry of Communication and Information, in the election of local leaders in the year 2018 , the participation rate was only $73,14 \%$. This number considered low, and the reason of it according to Antar Venus (UNPAD political communication expert) due to lag of education or dissemination of the system to the group of first time voters. While the number of this group is big as we can see in Table 1, it is understood if political parties make this group as a main target to get their votes. Their ignorance combined with irresponsible promotion and campaign will lead to bad choice and made contra productive to the political system itself in the end. Therefore, it is necessary and urgent to increase and establish the participation of the group and make it as a part of political education formally or informally.

First time voters' role in politic is important in politic democratic since the basis of deciding the leader among citizen is the greatest number. This phenomenon has been acknowledged since ancient Greek and Rome moving to medieval era, when they made a decision of leaders in Holy Roman Emperor. The tradition when Aristotle introduced a polis country where the representative of citizen chosen according to certain criteria and this chosen group has an authority to administer their citizen matters [3]. The same notion also happened in other side of the globe in the same era. Leaders election in Vedic era in India also applied the similar procedure, where the King of Gana tribe chosen by Gana community itself, although the criterion for it was clear: the candidate 
should come from kshatriya varna which the son of previous King in practice, but the final decision is in Gana community [4].

Democratic modern as we know has been introduced in seventh century when England amended Magna Charta with gave more freedom for citizen in the form of right to choose parliament member which was known as Bill of Right [5].

Democracy comes from Greek language demokratia which is from demos (people) and kratos (power), then it is the power of people. In democracy country, the voice of people that count for choosing their leader. Mechanism to get this voice through general election commonly [6]. Every single voice of people is matter; including those come from first time voter. In the beginning, citizen that have right to choose limited to whom age beyond 25 years old that can be traced to Croatia Republic election in 1755-1769 [7].

In Indonesia, the limitation of age to choose in general election decrease from 1948 to 1969. According to the Law No. 27 Year 1948, the age to choose limited to 18 years old, and the age was decreased to 17 years old in 1969, and this age is implied until recent election. It is recorded that the limitation of 17 years old has been 7 times implied in the general election in Indonesia.

Interestingly, some other countries applied age minimum lower than Indonesia, and some others applied higher. The countries such as Nicaragua, Scotland, and Brazil set the age minimum is 16 years old; while Taiwan, Bahrain, and Malaysia applied $18-20$ years old. There are critics for age minimum 16 years old that said this group of age has not in labor yet therefore they do not categorize as tax payer, and have no house yet. On the other hand, these three criteria become indicator for determine for right to choose relates to social maturity, i.e. ability to choose based on leader candidates' program not merely the person itself.

On the other hand, the same critics goes to age minimum of 18 years old above. The main argument is the group of age have less interest in politic. In independent referendum in Scotland in 2014 for example, it is evidence that the group of age 16 and 17 years old showed more interest to politic than those age 18 years old above. The reason of the group of 18 years old have less interest in politic due to lack of information of candidates' capability to choose. Most of them seek such information by their own up to the level they confident to make a choice; and the number of their participant lower then [8].

Over all, the first time voters acknowledged have significant contribution for election worldwide. According to BBC News, the role is well noticed by the group indeed. One of the respondent that interviewed by BBC News, Cowling said that this group have 
positive role toward program offered by candidates, therefore the candidates would embrace issues related to this group such as low paying jobs and unsecure, school fee, and low budget housing [9].

\section{Methods and Equipment}

This research was undertaken by using mix method research between quantitative and qualitative method. Quantitative is used to support qualitative analysis which relates to perception and participation of higher education student in general election.

Using primary, secondary, and tertiary sources of data, this research classified the data according to those types of sources data. Primary data mainly gathered from data and information through questionnaire and interview directly with respondents. Questionnaire has been distributed to relevant respondents with representativeness of research subject take into consideration. Under this criteria, respondents that participated to this research are students from UNJ, As Safiiyah, Trisakti, IISIP, and Yarsi. Each university consists of 12 students.

Secondary data for this research in the form of legal resources or documents such as regulations, books, journals, scientific magazines, and relevant research results.

As mentioned above that relevant research was important to this research, and also becomes state of the art of the research, here is some of publications relate to first time voter in the last 5 years: (1) Young-Adult Voting: An Analysis of Presidential Elections, 1964-2012 conducted by Thom File, 2014; (2) Pandangan Pemilih Pemula Terhadap Pemilihan Umum Di Indonesia (Kajian terhadap pandangan siswa SMA Pangudi Luhur Van Lith Muntilan terhadap Pemilu Legislatif dan Pemilu Presiden) conducted by Y. Hartono dan E. Mery Christian Putri, 2015; (3) Partisipasi Politik Pemilih Pemula Pada Pemilihan Walikota Semarang di Kota Semarang, conducted by Eta Yuni Lestari dan Nugraheni Arumsari, 2018; (4) Tingkat Kesadaran Politik Pemilih Pemula dalam Pemilihan Umum Bupati Dan Wakil Bupati Kabupaten Lanny Jaya Provinsi Papua (Suatu Studi di Distrik Pirime), conducted by Werpen Wenda, 2018; and (5) Partisipasi Politik Pemilih Pemula dalam Pemilihan Umum conducted b Primandha Sukma Nur Wardhani, 2018.

\section{Results}

The result of questionnaire can be classified into 3 categories: knowledge of regulations, system of election, and perception towards election system through open answer that 
describe respondents answers further. For the knowledge of regulation, the respondents mainly less know of election regulation.

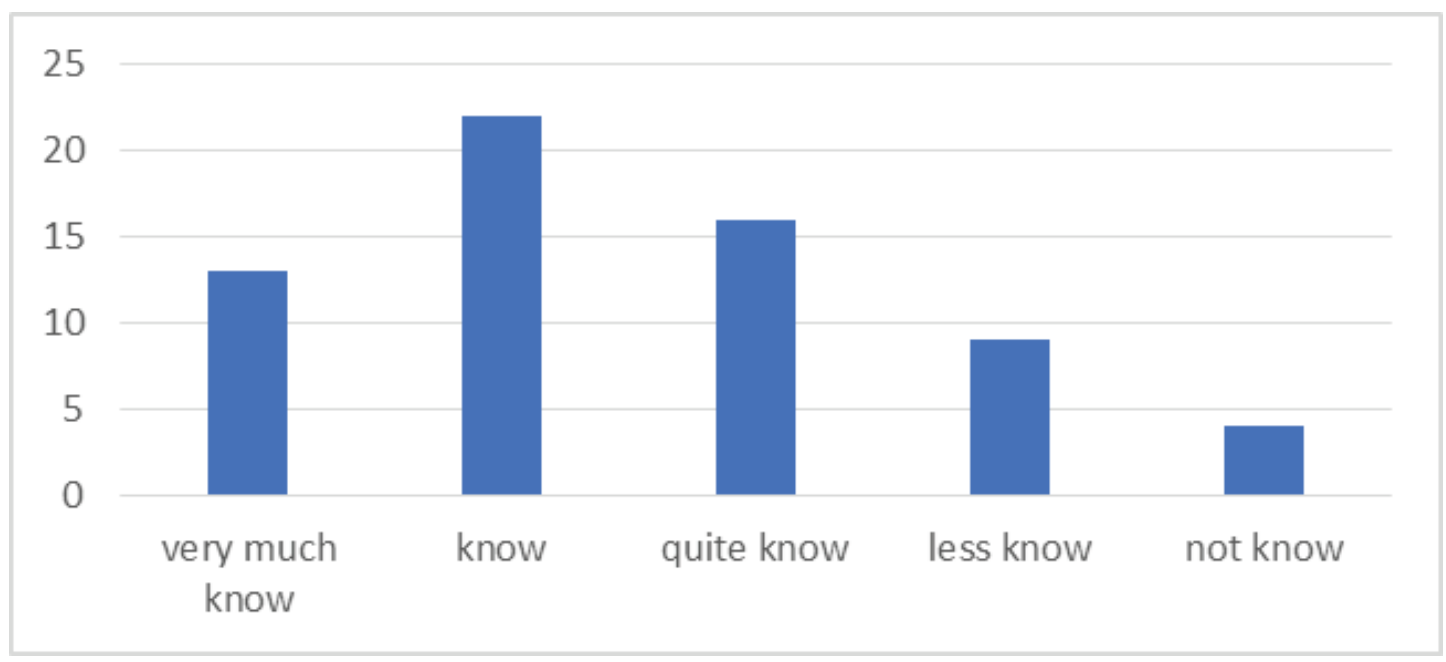

Figure 1: Knowledge of Election Regulation

The data show that the group of age relatively know with tends ignorance to regulation of election system. While we know that awareness of the regulation becomes a basic for making good and reasonable choice in the election.

Unlike the knowledge of regulation, respondents know well about principle in general election, i.e. direct (langsung), public (umum), free (bebas), secret (rahasia).

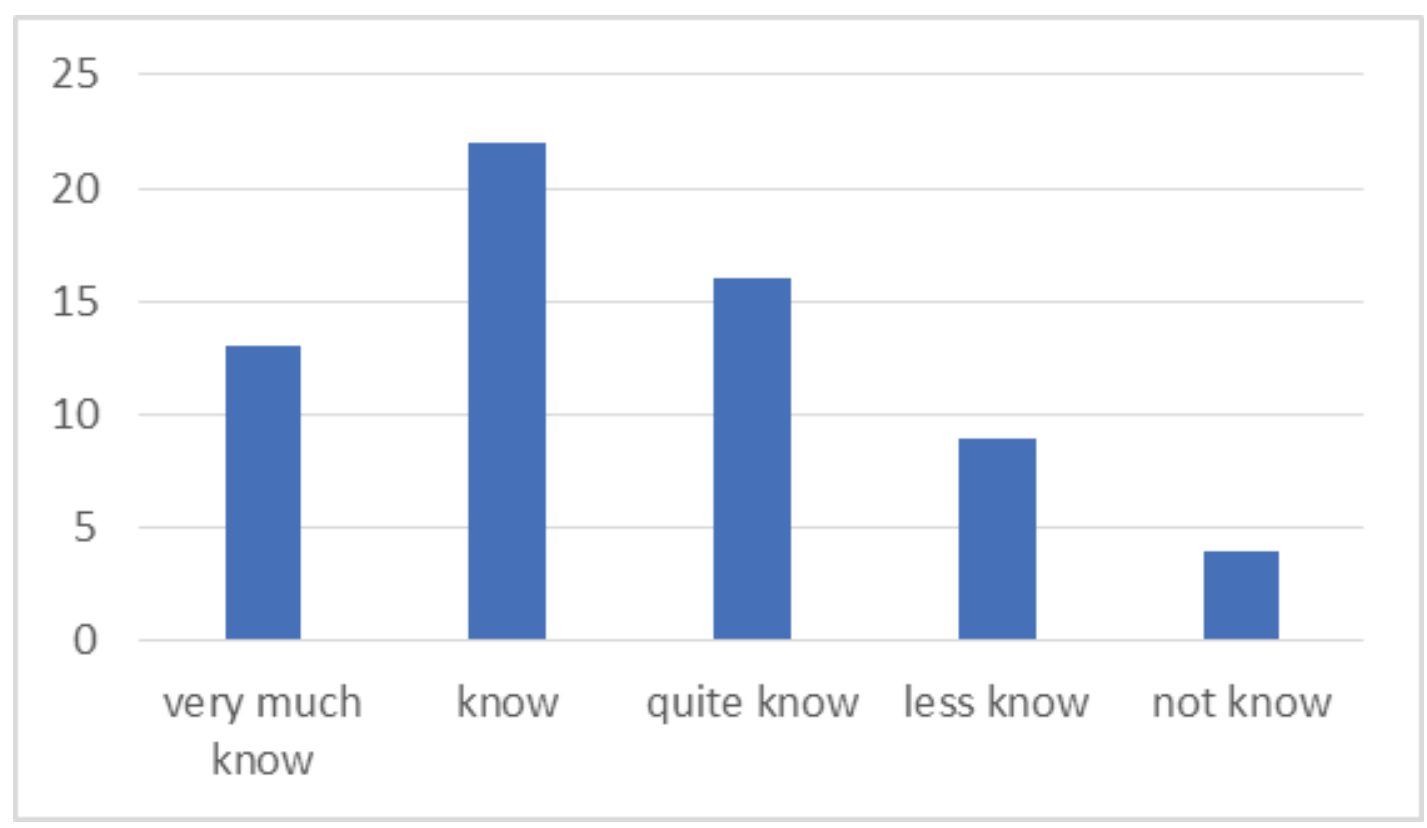

Figure 2: Knowledge of Election Principle

The knowledge of the respondents of the implementation of election in Indonesia also vary from not aware into well aware. 


\section{Times of Election in Indonesia}

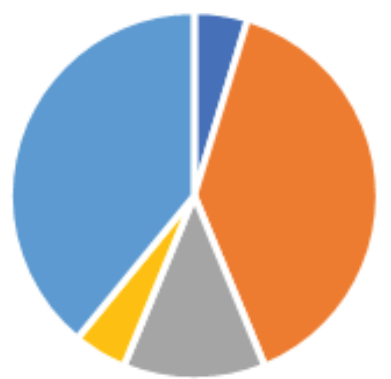

- three times

six times
- four times

- more than six times

Figure 3: Time of Election in Indonesia

This is relevant with the answer of respondent about when the last general election took place; which most of the respondents (51) answer in the year 2014. However, most of respondents do not familiar with the procedure of the election; only $28(43,75 \%)$ answered correctly. The similar answers also for procedure for registration of voters; only 33 (51,56\%) know well the procedure. Interestingly, respondents know very well if the disputes occurred because of the election system; 51 (79,69\%) said it must be processed in Constitution Court.

Other knowledge of election system of respondents regarding the function of institution of Election Commission and Supervisor Election can be described as follow:

TABLE 2: The results of Other Knowledge

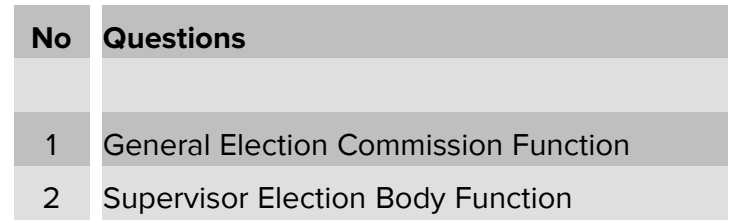

2 Supervisor Election Body Function

\begin{tabular}{|c|c|c|c|c|}
\hline \multicolumn{5}{|c|}{ Answers } \\
\hline 1 & 2 & 3 & 4 & 5 \\
\hline 5 & 45 & 9 & 4 & 0 \\
\hline 3 & 38 & 17 & 6 & 0 \\
\hline
\end{tabular}

Most of respondents aware about function of institution related to general election system. Perception of the students toward general election system in Indonesia can be classified into 8 groups which can be describe as follow:

Various perceptions can be seen from the Table above. The five highest answer covers:

1. Respondent said that is necessary to make direct election $(57,81 \%)$ which means that every single vote counts. Every citizen has a right to chose directly toward 
TABLE 3: The Perception of the Students Towards the General Election

\begin{tabular}{|c|c|c|c|c|c|c|}
\hline \multirow[t]{2}{*}{ No } & \multirow[t]{2}{*}{ Questions } & \multicolumn{5}{|c|}{ Answers } \\
\hline & & 1 & 2 & 3 & 4 & 5 \\
\hline 1 & $\begin{array}{l}\text { Relevance of regulation with society needs of } \\
\text { democracy }\end{array}$ & 2 & 34 & 14 & 11 & 2 \\
\hline 2 & $\begin{array}{l}\text { Implementation of the election principles } \\
\text { (LUBER) }\end{array}$ & 0 & 9 & 27 & 24 & 3 \\
\hline 3 & $\begin{array}{l}\text { Phenomenon pursuing voters through money } \\
\text { compensation }\end{array}$ & 2 & 2 & 8 & 31 & 19 \\
\hline 4 & Negative campaign & 2 & 4 & 19 & 28 & 18 \\
\hline 5 & Black campaign & 2 & 1 & 8 & 16 & 34 \\
\hline 6 & Relevance of election at the same time & 7 & 27 & 20 & 4 & 3 \\
\hline 7 & Relevance of direct election & 6 & 37 & 12 & 4 & 2 \\
\hline 8 & Sufficient voters character & 5 & 23 & 30 & 4 & 0 \\
\hline
\end{tabular}

candidates and political party they want to. The answer in the range quite or enough that means not so strong;

2. Regulations relates to election system has been considered quite relevant $(53,12 \%)$ which means respondents see that all regulations taken place right now sufficient to support election system;

3. The same amount $(53,12 \%)$ did not approve using black campaign. However, there is $3,12 \%$ of the respondents strongly agree using black campaign in the process;

4. Regarding phenomenon that candidates used money to pursue voters, only 48 , $44 \%$ disagree, and $28,13 \%$ strongly disagree. However, there is around 23,43 agree to this behavior;

5. Moderate answers come from respondents regarding character of the voters. In democratic system, the equality of understanding the rule of the game is necessary, since all element of the society have right come to the center of the game. Therefore, ability to choose wisely is the key getting best results. However, the respondent only answer to this issue moderately $(46,86 \%)$, only $7,81 \%$ strongly agree;

6. Regarding using negative campaign in the election system in order to increase vote numbers as commonly used by candidates, only $43,75 \%$ quite disagree, significant number even agree to that behavior reach $28,12 \%$ which means together respondents tends to agree using negative campaign in election system. 


\section{Discussion}

Regarding the result, it is noted that there is no significant relation between the knowledge of election system and the reason involved in the system intensively in order to make the system better for the firs time voter group. Although this group willing to elaborate their knowledge of election system, somehow they only want to know what the system is; not to understand what the goal of the system. The contradiction can be seen through respondents answer about using negative and black campaign in the election system; most of the respondent agree using them in election process. The similar perception toward money politic, which is only 76,57 disagree and strongly disagree.

Regarding administration of the election system, the group is still considered that the election system in moderate stage of implementing its principle; not strong enough. This means, from the perspective of the first time voters the Government has not yet do their best effort to implement the principle of the election system. However, the intention of implement direct election is strong enough, which means they want their vote related closely to the person or party they choose. The perception of same time election in the moderate level of agree, which means the group do not see the importance of separate or same time election.

Considering the trend of the answer above, first time voters group still struggling in defining their role in election system. The struggling can be seen in the term of what kind voters that could be contributed significantly for better election system. Most of the respondents still tolerate to the black, negative, and money politics.

Phenomenon above indicates that the first time voters group needs to be involved in discussion and dissemination of election system so that they will be able to formulate the system needed associated to Indonesian culture and conditions. The best way in doing so is making time and duration sufficiently in the relevant subject in higher education system. According to policy of Ministry of Higher Education, there are four subjects that must be delivered to the students in the term of character building, i.e.: religion, Indonesian language, Pancasila, and civics. The subject could be inserted in Pancasila and civics.

\section{Conclusion}

The conclusion of this research: 
1. Most of the first time voters have a relevant and sufficient knowledge about general election system; this can be supported by information technology that access easily and familiar to the group;

2. The first time voters are still struggling in defining their role in the election system; most of them seen the election as their right to involve in making a choice directly for leaders of the country; not so much in the position of which criteria or what kind of leaders that they want to lead the countries for better future;

3. In order to less the struggle, it is necessary to making a time and duration in certain subject, such as Pancasila or Civic Education for discussing the system sufficiently so that the first time voters group could be understand the system better.

\section{Acknowledgement}

The authors would like to thanks Vara and Kurniawan for helping gathering and coding the data.

\section{Funding}

This research is funded by the Faculty of Social Sciences, Universitas Negeri Jakarta through research grand year 2019.

\section{Conflict of Interest}

The authors have no conflict of interest to declare.

\section{References}

[1] Daniel, S., Lev. (1990). Hukum dan Politik di Indonesia: Kesinambungan dan Perubahan. Jakarta: LP3ES, p. xii.

[2] Ministry Internal Affair Estimated that over 5.035.887 of First Time Voters in the Year 2019. Daftar Penduduk Pemilih Potensial Pemilu (DP4).

[3] Encyclopedia Britanica Online: Election (Political Science).

[4] Eric, W. R. (1997). The First Democracies: Early Popular Government Outside Athens. Franz Steiner Verlag.

[5] “Britain's unwritten constitution”. British Library. Retrieved 27 November 2015. 
[6] Oxford English Dictionary: Democracy.

[7] Robert, P. (April 2006). By the Law or the Sword: Peterloo Revisited. Journal History, vol. 91, issue 2(302), pp. 254-276.

[8] Worldatlas, (2019, April). Legal Voting Age by Country. Retrieved from https://www. worldatlas.com/articles/legal-voting-age-by-country.html.

[9] BBC News, (2017, May). 